\title{
The effects of additional treatment with terguride, a partial dopamine agonist, on hyperprolactinemia induced by antipsychotics in schizophrenia patients: a preliminary study
}

This article was published in the following Dove Press journal:

Neuropsychiatric Disease and Treatment

22 August 2014

Number of times this article has been viewed

\author{
Kojiro Hashimoto \\ Norio Sugawara \\ Masamichi Ishioka \\ Kazuhiko Nakamura \\ Norio Yasui-Furukori \\ Department of Neuropsychiatry, \\ Graduate School of Medicine, \\ Hirosaki University, Hirosaki, Japan
}

Correspondence: Norio Yasui-Furukori Department of Neuropsychiatry, Graduate School of Medicine, Hirosaki University, Zaifu-cho 5, Hirosaki City 036-8562, Aomori, Japan

Tel $+81 \quad 172395352$

Fax $+81 \quad 172395352$

Email yasufuru@cc.hirosaki-u.ac.jp
Abstract: Hyperprolactinemia is a frequent consequence of treatment with antipsychotics. Earlier studies have indicated that terguride, which is a partial dopamine agonist, reduces the prolactin levels that are induced by prolactinemia. Thus, we examined the dose effects of adjunctive treatment with terguride on the plasma concentrations of prolactin in patients with elevated prolactin levels resulting from antipsychotic treatment. Terguride was concomitantly administered to 20 schizophrenic patients (10 males and 10 females) receiving paliperidone and risperidone. The dose of terguride was $1.0 \mathrm{mg} /$ day. Sample collections for prolactin were conducted before terguride (baseline) and 2-4 weeks after administration. The samples were obtained after the morning dose of terguride. The average ( \pm standard deviation) plasma prolactin concentration during terguride coadministration was significantly lower than the baseline concentration in females $(82.3 \pm 37.1 \mathrm{ng} / \mathrm{mL}$ versus $56.5 \pm 28.5 \mathrm{ng} / \mathrm{mL}, P<0.01)$ but not in males $(28.8 \pm 18.0 \mathrm{ng} / \mathrm{mL}$ versus $26.2 \pm 13.1 \mathrm{ng} / \mathrm{mL}$, not significant). Additionally, a significant correlation between the ratio of prolactin reduction and the baseline prolactin concentration was identified in males $\left(r_{\mathrm{s}}=-0.638, P<0.05\right)$ but not in females $\left(r_{\mathrm{s}}=-0.152\right.$, not significant $)$. Many patients complained of various adverse events following terguride administration, such as insomnia, agitation, and/or the aggravation of hallucinations. This study suggests that additional treatment with terguride decreases the prolactin concentrations in females experiencing high prolactin levels as a result of antipsychotic treatment. However, its utility for schizophrenia may be diminished because of its low tolerability.

Keywords: hyperprolactinemia, terguride, adjunctive treatment, schizophrenia

\section{Introduction}

Hyperprolactinemia is a frequent consequence of treatment with antipsychotic agents, which induce increased prolactin concentrations. ${ }^{1,2}$ The major effects of hyperprolactinemia in women include amenorrhea, galactorrhea, loss of libido, cessation of normal cyclic ovarian function and occasional hirsutism, ${ }^{1,2}$ and a long-term risk of osteoporosis. ${ }^{3}$ The effects in men include loss of libido, impotence, hypospermatogenesis, ${ }^{1,2}$ and a long-term risk of low bone density. ${ }^{3}$

There are several medical strategies that target hyperprolactinemia. Costa et $\mathrm{al}^{4}$ reviewed the effects that bromocriptine, cabergoline, cyproheptadine, amantadine, and selegiline had on sexual dysfunction in patients who were treated with antipsychotics and suggested that this effect was most likely caused by hyperprolactinemia. The primary mechanisms of bromocriptine and cabergoline involve a direct 
dopamine agonistic profile. Amantadine causes an increase in dopamine release and reduced dopamine and noradrenaline reuptake into synaptic terminals, whereas selegiline is a selective monoamine oxidase B inhibitor. All of these drugs have dopamine agonistic effects. ${ }^{4}$ However, because psychotic side effects have been demonstrated with these medications, their utility for schizophrenia has been limited to date.

Terguride, a 9, 10-transdihydrogenated derivative of the ergot alkaloid lisuride, has been reported to exhibit both agonistic and antagonistic pharmacological effects at the dopamine D2 receptors, depending on the locations and states of the receptors. ${ }^{5-8}$ Similarly to D2 agonists, such as bromocriptine, terguride inhibits the hypersecretion of prolactin in reserpinized rats at low doses, which suggests a potent agonistic action on the pituitary dopamine D2 receptors. ${ }^{6}$ However, unlike D2 agonists, terguride does not induce stereotypy or hyperlocomotion at high doses in rats compared with bromocriptine, ${ }^{8}$ which suggests that it does not stimulate the postsynaptic D2 receptors in the central dopaminergic systems. There have been several reports supporting the significant lowering effect of terguride on the prolactin levels in hyperprolactinemic women due to prolactinoma $^{9-13}$ and showing that this effect of terguride was dose-dependent and that the treatment was well-tolerated. When coadministered with antipsychotics, terguride may bind to the dopamine receptor more robustly and act as a dopamine receptor agonist in an antipsychotic-induced hypodopaminergic state. To our knowledge, there is little information regarding the effect of terguride on hyperprolactinemia during antipsychotic treatment.

Thus, the present study aimed to determine the effects of an additional treatment with terguride, which is a dopamine partial agonist, on prolactin concentrations and the associated sexual dysfunctions that are induced by antipsychotics in schizophrenia patients.

\section{Methods}

Twenty-three outpatients (10 males and 13 females) who fulfilled the criteria for schizophrenia (paranoid type in 20 cases and undifferentiated type in three cases) according to the Diagnostic and Statistical Manual of Mental Disorders, fourth edition participated in this study. Three female patients were withdrawn from this study at their own requests several days after the $1.0 \mathrm{mg}$ /day dose of terguride coadministration was initiated because they felt uncomfortable. The characteristics of the subjects, such as age, body weight, and duration of illness, are shown in Table 1. The study was approved by the Hirosaki University Ethics Committee, and written
Table I Characteristics of subjects

\begin{tabular}{|c|c|c|}
\hline & Males $(n=10)$ & Females $(n=10)$ \\
\hline Age (years) & $42.5(9.0)$ & $43.3(12.4)$ \\
\hline Height (cm) & I $67.9(5.4)$ & $154.7(2.9)^{*}$ \\
\hline Body weight (kg) & $72.2(9.0)$ & $55.1(6.3)^{*}$ \\
\hline $\begin{array}{l}\text { Duration of illness } \\
\text { (years) }\end{array}$ & $15.0(6.6)$ & $14.9(5.2)$ \\
\hline $\begin{array}{l}\text { Duration of current } \\
\text { medication (months) }\end{array}$ & $26.4(I I .2)$ & $27.0(13.1)$ \\
\hline \multicolumn{3}{|l|}{ dose (mg/day) } \\
\hline Paliperidone & $7.7(3.2)$ & $7.7(3.2)$ \\
\hline Risperidone & 6 & $4.3(1.2)$ \\
\hline \multicolumn{3}{|l|}{ Prolactin levels (ng/mL) } \\
\hline Before terguride & $28.8(18.0)$ & $82.3(37.1)^{* *}$ \\
\hline After terguride & $26.2(\mid 3 . I)$ & $56.5(28.5)^{* *}$ \\
\hline \multicolumn{3}{|l|}{$\begin{array}{l}\text { Adverse event } \\
\text { (number) }\end{array}$} \\
\hline Anxiety & 0 & 2 \\
\hline Agitation & 2 & I \\
\hline Insomnia & 0 & I \\
\hline Hallucination & 1 & 2 \\
\hline Sedation & 1 & I \\
\hline
\end{tabular}

Notes: Data include mean (standard deviation). $* P<0.00$ I, compared with males. $* * P<0.0$ l, compared with males.

informed consent to participate in this study was obtained from the patients.

Prior to terguride coadministration, the subjects had received paliperidone once per day ( $8 \mathrm{am})$ in 16 cases and risperidone once per day $(8 \mathrm{pm})$ in four cases. The median (range) doses of paliperidone and risperidone were 6 (3-12) $\mathrm{mg} /$ day and 4.5 (3-6) ng/day, respectively. The coadministered drugs included flunitrazepam (2-4 mg/day) in eight cases, biperiden (3-6 mg/day) in seven cases, sennoside (12-36 mg/day) in five cases, and diazepam (2-6 mg/day) in one case. We fixed the doses of these coadministered drugs throughout the study period. We confirmed that the female patients did not receive oral contraceptives. There were seven premenopausal and three postmenopausal females in our study, including four patients who had menstrual abnormalities. Terguride $(0.5 \mathrm{mg}$ twice per day at 8 am and $8 \mathrm{pm}$ ) was coadministered to all subjects for the first 2-4 weeks according to a product attachment document from the pharmaceutical company. The plasma sample collections for determining prolactin concentrations were performed before and 2-4 weeks after terguride coadministration at 10-11 am.

On the same day as the blood samplings, sexual dysfunction side effects were evaluated using seven items from the Udvalg for Kliniske Undersøgelser side-effect rating scale. ${ }^{10}$ Two investigators (one male and one female), who 
were blind to the drug regimens and expected consequences of the administered drug concentrations, performed these clinical assessments. The investigators recorded information on the following items: sexual side effects (increased or diminished sexual desire, erectile, ejaculatory, or orgasmic dysfunction, and vaginal dryness) and other reproductive side effects (menorrhagia, amenorrhea, galactorrhea, and gynecomastia).

The plasma concentrations of prolactin were quantified using an enzyme immunoassay (IMX Prolactin Dinapack; Dainabot Ltd., Tokyo, Japan). The normal ranges for prolactin for men and women are $3.6-12.8 \mathrm{ng} / \mathrm{mL}$ and $6.1-30.5 \mathrm{ng} / \mathrm{mL}$, respectively. The intraassay and interassay coefficient variation values were both less than $5.6 \%$ at plasma concentrations of $8.0 \mathrm{ng} / \mathrm{mL}, 20.0 \mathrm{ng} / \mathrm{mL}$, and $40.0 \mathrm{ng} / \mathrm{mL}$. The limit of detection for prolactin was $1.0 \mathrm{ng} / \mathrm{mL}$.

Student's $t$-tests were used to compare the patient data, including the prolactin concentrations before and after terguride, between males and females. Paired $t$-tests were used to compare the plasma concentrations of prolactin before and during terguride treatment. Spearman correlation analyses were used to assess the correlation between the degree of prolactin reduction and the baseline prolactin concentration.
A $P$-value $<0.05$ was regarded as significant. We used SPSS 21.0 for Windows (SPSS Japan Inc., Tokyo, Japan) for the statistical analyses.

\section{Results}

The prolactin concentrations before and after the terguride treatment in females were both significantly higher than those in males, although there were no differences in the characteristics of the subjects except height and body weight between males and females (Table 1). Therefore, sex-specific data analyses were conducted.

Terguride significantly decreased the plasma concentrations of prolactin in all subjects (mean \pm standard deviation: $55.5 \pm 39.5 \mathrm{ng} / \mathrm{mL}$ versus $41.4 \pm 26.6 \mathrm{ng} / \mathrm{mL}, P<0.01)$. The average prolactin plasma concentration during terguride coadministration was significantly lower than the baseline in females $(82.3 \pm 37.1 \mathrm{ng} / \mathrm{mL}$ versus $56.5 \pm 28.5 \mathrm{ng} / \mathrm{mL}, P<0.01)$ but not in males $(28.8 \pm 18.0 \mathrm{ng} / \mathrm{mL}$ versus $26.2 \pm 13.1 \mathrm{ng} / \mathrm{mL}$, not significant) (Figure 1).

Overall, a significant correlation between the degree of prolactin reduction and the baseline prolactin concentration was identified $\left(r_{\mathrm{s}}=-0.583, P<0.01\right)$. This correlation was
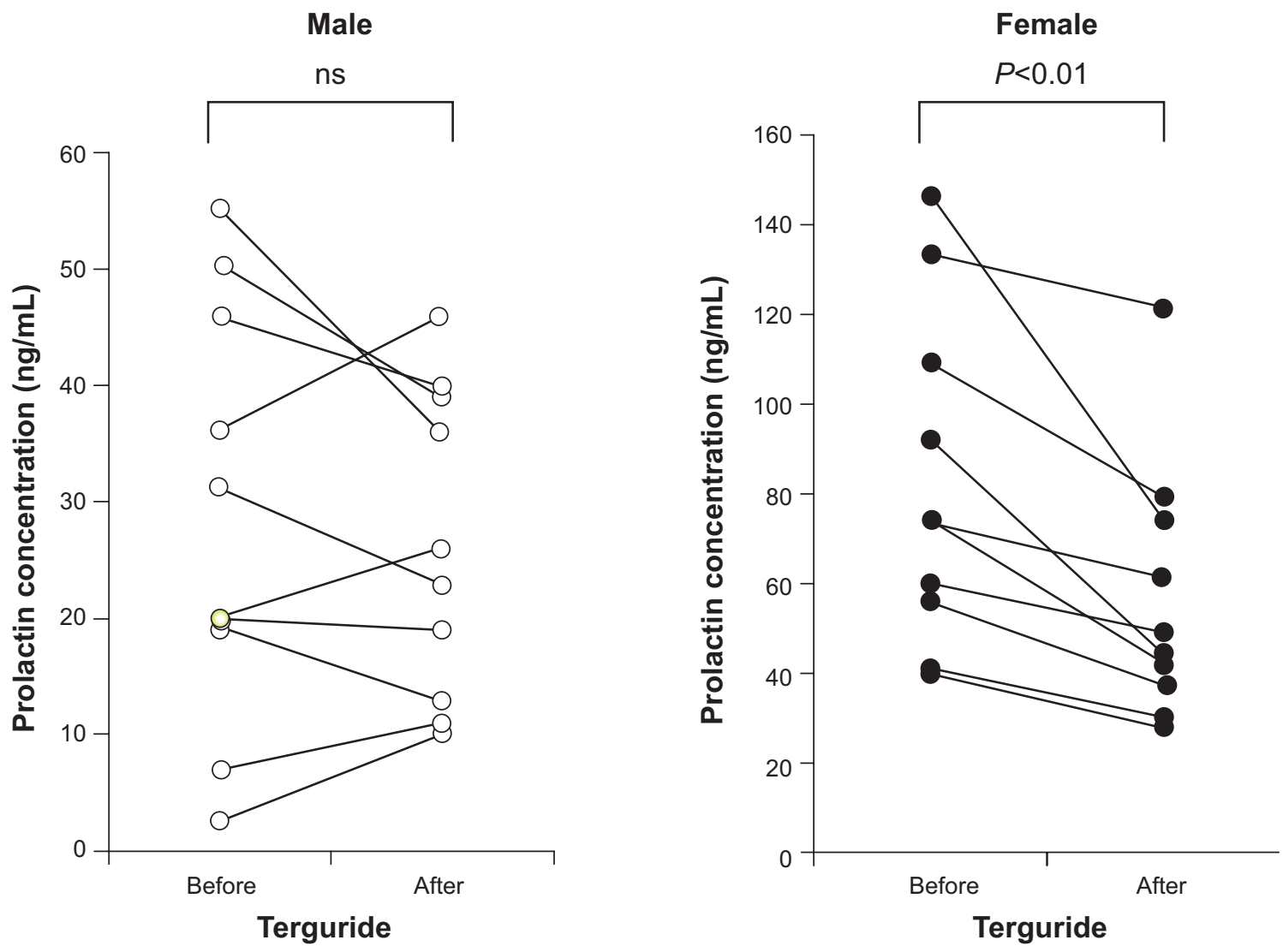

Figure I Individual changes in prolactin concentrations before and after the adjunctive administration of terguride in males (left) and females (right). Abbreviation: ns, not significant. 
observed in males $\left(r_{\mathrm{s}}=-0.638, P<0.05\right)$ but not in females $\left(r_{\mathrm{s}}=-0.152\right.$, not significant) (Figure 2 ).

Of the 23 patients, including the dropout cases, approximately half complained of various adverse events after terguride administration, such as agitation in five cases, insomnia in two cases, anxiety in three cases, deterioration of hallucinations in three cases, and sleepiness and/or fatigue in two cases. No patients showing improvement in negative symptoms were observed. No adverse events were reported in ten cases, but six of these individuals wanted to withdraw from the study 4 weeks after terguride administration. Finally, terguride was maintained in four patients. An improvement in sexual dysfunction, such as erectile, ejaculatory, and orgasmic dysfunctions, was reported in two males, in whom the prolactin concentration decreased from $50.3 \mathrm{ng} / \mathrm{mL}$ to $39.0 \mathrm{ng} / \mathrm{mL}$ and from $55.1 \mathrm{ng} / \mathrm{mL}$ to $36.0 \mathrm{ng} / \mathrm{mL}$, respectively, during terguride administration. The remaining patients did not report any changes in sexual function.

\section{Discussion}

The results of the present study demonstrated that the additional treatment with terguride in patients taking antipsychotics induced a significant decrease in the plasma concentrations of prolactin in women but not in men. These findings represent the first report to suggest that terguride has a significant effect on prolactin concentrations that have been elevated by antipsychotics, although this phenomenon was observed to be sex-specific.

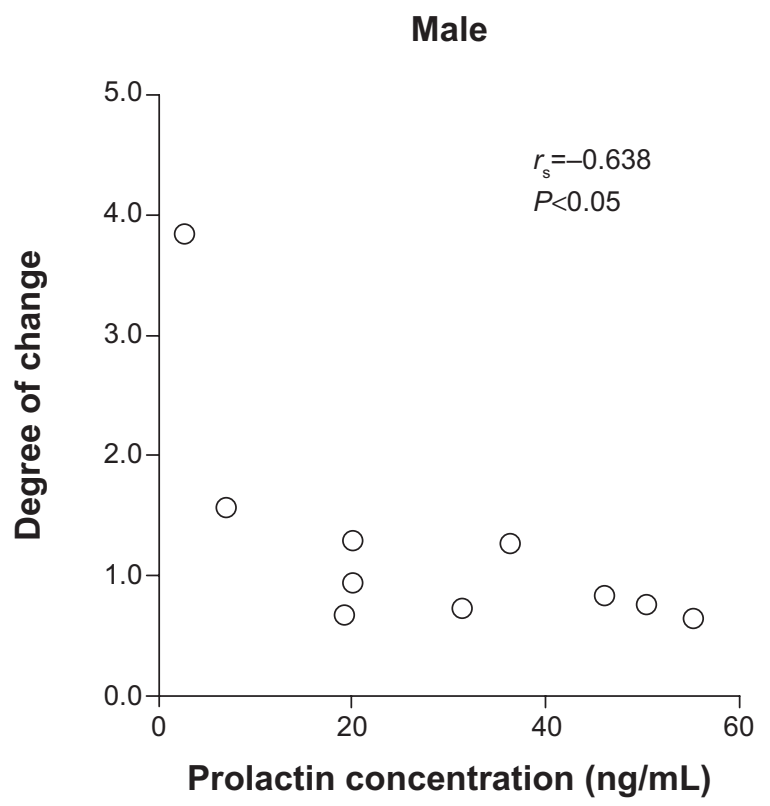

Terguride is a potent partial dopamine D2 agonist. ${ }^{5-8}$ Based on its pharmacology, this medication may be an ideal adjunctive treatment for secondary hyperprolactinemia. Its pharmacological profile is similar to that of aripiprazole. The percent decrease in prolactin levels that was observed in the controls during terguride coadministration was comparable with that induced by aripiprazole. The effects of additional treatment with aripiprazole on schizophrenic patients with antipsychoticinduced hyperprolactinemia have been demonstrated in many studies, ${ }^{14-27}$ although aripiprazole is more commonly used alone. We reported a dose-dependent effect of the concomitant administration of aripiprazole in schizophrenic female patients with hyperprolactinemia. The $3 \mathrm{mg} /$ day dose of aripiprazole induced a significant reduction in prolactin levels, but this effect plateaued at doses of $>6 \mathrm{mg} /$ day of aripiprazole. However, this combination of antipsychoics should be avoided because worsening of cognitive function has been demonstrated in adjunctive treatment with aripiprazole, ${ }^{28}$ and the simplification of antipsychotics has been shown to enhance cognitive function. ${ }^{29}$

Terguride reduced prolactin concentrations in females, whereas it did not alter these concentrations in males. Although we do not have a clear explanation for this sexspecific difference, it may be attributable to the different prolactin concentrations that exist in males and females before concomitant terguride treatment. In males with relatively low prolactin concentrations at the baseline compared with females, terguride might increase the prolactin concentrations, most likely because of its partial dopamine

Correlations between the ratio of change for prolactin and baseline prolactin in males (left) and females (right) Abbreviation: ns, not significant. 
agonistic property. However, plasma prolactin levels are easily influenced by a variety of factors such as stress. In contrast, terguride decreased prolactin concentrations in all of the females with higher concentrations at baseline, which was most likely because of its partial dopamine antagonistic property. In fact, an inverse correlation between the ratio of prolactin change and baseline prolactin levels was identified in this study using analysis with total subjects as well as using analysis with male subjects.

In this study, erectile, ejaculatory, or orgasmic dysfunctions were ameliorated in two males, which was most likely due to of the reduction in prolactin concentrations that occurred during the terguride treatment. Therefore, it may be regarded as a potential therapy in patients with sexual dysfunction that is induced by antipsychotics. However, the frequency of adverse effects associated with terguride was very high in this study, whereas almost no side effects of aripiprazole were observed, ${ }^{27}$ suggesting that the utility of terguride in schizophrenia may be diminished because of its low tolerability. This discrepancy may be explained by the difference in dopamine agonistic activity between terguride and aripiprazole. Compared with aripiprazole, terguride has a higher affinity for the dopamine receptor and acts as a partial dopamine agonist, and it has been suggested that the intrinsic activity of terguride at the human dopamine D2 receptor is $1.4-1.6$ times stronger than aripiprazole..$^{30}$ The intrinsic activity of terguride has been reported to be $42 \%$ at dopamine receptors, while the similar intrinsic activity of aripiprazole has been estimated at $17 \%{ }^{31}$

There were several limitations in this study. First, the design of study was not well established. The number of subjects in this study was small $(n=20)$, and there was no placebo. There was also no indication of the measures of psychopathology or of the side effects. We did not confirm whether the terguride dose $(1.0 \mathrm{ng} / \mathrm{mL})$ was lower or higher than ideal to minimize hyperprolactinemia. Moreover, the study period of 2-4 weeks may have been too short to confirm the effects of the additional treatment with terguride on menstrual irregularities and disturbances. The baseline prolactin levels were not very high. Finally, the plasma terguride concentrations were not measured. The combination of terguride and antipsychotics could cause a drug-drug interaction, although whether both drugs are substrates of CYP2D6 and CYP3A4 is not known. ${ }^{32}$ Therefore, further studies such as multicenter, double-blinded placebocontrolled trials are required to confirm our findings.

In conclusion, this study indicated that additional treatment with terguride decreased prolactin concentrations that have been elevated by antipsychotic treatments in females but not in males. However, terguride's clinical utility may be diminished because of its adverse effects.

\section{Disclosure}

This study was funded by a Grant-in-Aid for Scientific Research (KAKENHI) from the Japan Society for the Promotion of Research (JSPS, \# 20333734), the Mitsubishi Pharma Research Foundation, the Asteras Schizophrenia Research Foundation, and a grant from the Hirosaki Research Institute for Neuroscience. Norio Yasui-Furukori has received grant/ research support or honoraria from and spoken for Asteras, Dainippon, Eli Lilly, GlaxoSmithKline, Janssen-Pharma, Meiji, Mochida, Merck Sharp \& Dohme, Otsuka, Pfizer, Takada, and Yoshitomi. The remaining authors declare that they have no competing interests. The funders had no role in the study design, data collection/analysis, decision to publish, or preparation of the manuscript. The authors report no other conflicts of interest in this work.

\section{References}

1. Byerly M, Suppes T, Tran QV, Baker RA. Clinical implications of antipsychotic-induced hyperprolactinemia in patients with schizophrenia spectrum or bipolar spectrum disorders: recent developments and current perspectives. J Clin Psychopharmacol. 2007;27(6):639-661.

2. Bostwick JR, Guthrie SK, Ellingrod VL. Antipsychotic-induced hyperprolactinemia. Pharmacotherapy. 2009;29(1):64-73.

3. Meaney AM, Smith S, Howes OD, O'Brien M, Murray RM, O'Keane V. Effects of long-term prolactin-raising antipsychotic medication on bone mineral density in patients with schizophrenia. Br J Psychiatry. 2004;184:503-508.

4. Costa AM, Lima MS, Mari Jde J. A systematic review on clinical management of antipsychotic-induced sexual dysfunction in schizophrenia. Sao Paulo Med J. 2006;124(5):291-297.

5. Wachtel H, Dorow R. Dual action on central dopamine function of transdihydrolisuride, a 9,10-dihydrogenated analogue of the ergot dopamine agonist lisuride. Life Sci. 1983;32(4):421-432.

6. Kehr W. Transdihydrolisuride, a partial dopamine receptor antagonist: effects on monoamine metabolism. Eur J Pharmacol. 1984;97(1-2):111-119.

7. Stephens DN, Löschmann PA, Lanzinger C, WachtelH, Montgomery AM, Herberg LJ. Unusual interactions between the neuroleptic haloperidol, and the dopamine D2 partial agonist, terguride. Behav Pharmacol. 1990;1(6):521-529.

8. Yamaguchi M, Kimura-Iwasaki K, Akai T, Nakada Y, Nakagawa H. Terguride, a dopamine $\mathrm{D}(2)$ partial agonist, as a discriminative stimulus in rats. Behav Pharmacol. 1991;2(3):233-240.

9. Wachtel H, Dorow R, Sauer G. Novel 8 alpha-ergolines with inhibitory and stimulatory effects on prolactin secretion in rats. Life Sci. 1984;35(18):1859-1867.

10. Lingjaerde O, Ahlfors UG, Bech P, Dencker SJ, Elgen K. The UKU side effect rating scale. A new comprehensive rating scale for psychotropic drugs and a cross-sectional study of side effects in neuroleptic-treated patients. Acta Psychiatr Scand Suppl. 1987;334:1-100.

11. Venturini PL, Horowski R, Valenzano M, et al. Effect of terguride on prolactin levels in normal, puerperal and hyperprolactinaemic women. Eur J Clin Pharmacol. 1986;30(2):195-197.

12. Ciccarelli E, Touzel R, Besser M, Grossman A. Terguride - a new dopamine agonist drug: a comparison of its neuroendocrine and side effect profile with bromocriptine. Fertil Steril. 1988;49(4):589-594. 
13. Větr M, Talas M, Pohanka J, Gazárek F, Fingerová H. Terguride in the treatment of hyperprolactinemia. Acta Univ Palacki Olomuc Fac Med. 1990;125:155-160.

14. Kane JM, Carson WH, Saha AR, et al. Efficacy and safety of aripiprazole and haloperidol versus placebo in patients with schizophrenia and schizoaffective disorder. J Clin Psychiatry. 2002;63(9):763-771.

15. Casey DE, Carson WH, Saha AR, et al. Aripiprazole Study Group. Switching patients to aripiprazole from other antipsychotic agents: a multicenter randomized study. Psychopharmacology (Berl). 2003;166(4):391-399.

16. Marder SR, McQuade RD, Stock E, et al. Aripiprazole in the treatment of schizophrenia: safety and tolerability in short-term, placebocontrolled trials. Schizophr Res. 2003;61(2-3):123-136.

17. Lin SK, Chen CK. Reversal of antipsychotic-induced hyperprolactinemia, weight gain, and dyslipidemia by aripiprazole: a case report. J Clin Psychiatry. 2006;67(8):1307.

18. Wahl R, Ostroff R. Reversal of symptomatic hyperprolactinemia by aripiprazole. Am J Psychiatry. 2005;162(8):1542-1543.

19. Lee BH, Kim YK, Park SH. Using aripiprazole to resolve antipsychoticinduced symptomatic hyperprolactinemia: a pilot study. Prog Neuropsychopharmacol Biol Psychiatry. 2006;30(4):714-717.

20. Wolf J, Fiedler U. Hyperprolactinemia and amenorrhea associated with olanzapine normalized after addition of aripiprazole. J Clin Pharm Ther. 2007;32(2):197-198.

21. Shim JC, Shin JG, Kelly DL, et al. Adjunctive treatment with a dopamine partial agonist, aripiprazole, for antipsychotic-induced hyperprolactinemia: a placebo-controlled trial. Am J Psychiatry. 2007;164(9):1404-1410.

22. Chen $\mathrm{CH}$, Huang MC, Lu ML. Aripiprazole resolves symptomatic hyperprolactinemia in a male schizophrenic patient. Prog Neuropsychopharmacol Biol Psychiatry. 2008;32(3):893-894.

23. Lu ML, Shen WW, Chen CH. Time course of the changes in antipsychotic-induced hyperprolactinemia following the switch to aripiprazole. Prog Neuropsychopharmacol Biol Psychiatry. 2008;32(8):1978-1981.
24. Mir A, Shivakumar K, Williamson RJ, McAllister V, O'Keane V, Aitchison KJ. Change in sexual dysfunction with aripiprazole: a switching or add-on study. J Psychopharmacol. 2008;22(3):244-253.

25. Sheldrick AJ, Gründer G. Aripiprazole reduces serum prolactin in a woman with prolactinoma and acute psychosis. Pharmacopsychiatry. 2008;41(4):160

26. Byerly MJ, Marcus RN, Tran QV, Eudicone JM, Whitehead R, Baker RA. Effects of aripiprazole on prolactin levels in subjects with schizophrenia during cross-titration with risperidone or olanzapine: analysis of a randomized, open-label study. Schizophr Res. 2009;107(2-3):218-222.

27. Yasui-Furukori N, Kaneda A, Sugawara N, Tomita T, Kaneko S. Effect of adjunctive treatment with aripiprazole to atypical antipsychotics on cognitive function in schizophrenia patients. J Psychopharmacol. 2012;26(6):806-812.

28. Yasui-Furukori N, Furukori H, Sugawara N, Fujii A, Kaneko S. Dose-dependent effects of adjunctive treatment with aripiprazole on hyperprolactinemia induced by risperidone in female patients with schizophrenia. J Clin Psychopharmacol. 2010;30(5):596-599.

29. Hori H, Yoshimura R, Katsuki A, Sugita AI, Atake K, Nakamura J. Switching to antipsychotic monotherapy can improve attention and processing speed, and social activity in chronic schizophrenia patients. J Psychiatr Res. 2013;47(12):1843-1848.

30. Tadori Y, Miwa T, Tottori K, et al. Aripiprazole's low intrinsic activities at human dopamine D2L and D2S receptors render it a unique antipsychotic. Eur J Pharmacol. 2005;515(1-3):10-19.

31. Tadori Y, Kitagawa H, Forbes RA, McQuade RD, Stark A, Kikuchi T. Differences in agonist/antagonist properties at human dopamine $\mathrm{D}(2)$ receptors between aripiprazole, bifeprunox and SDZ 208-912. Eur J Pharmacol. 2007;574(2-3):103-111.

32. Urichuk L, Prior TI, Dursun S, Baker G. Metabolism of atypical antipsychotics: involvement of cytochrome p450 enzymes and relevance for drug-drug interactions. Curr Drug Metab. 2008;9(5):410-418.
Neuropsychiatric Disease and Treatment

\section{Publish your work in this journal}

Neuropsychiatric Disease and Treatment is an international, peerreviewed journal of clinical therapeutics and pharmacology focusing on concise rapid reporting of clinical or pre-clinical studies on a range of neuropsychiatric and neurological disorders. This journal is indexed on PubMed Central, the 'PsycINFO' database and CAS,

\section{Dovepress}

and is the official journal of The International Neuropsychiatric Association (INA). The manuscript management system is completely online and includes a very quick and fair peer-review system, which is all easy to use. Visit http://www.dovepress.com/testimonials.php to read real quotes from published authors. 